\title{
Treatment of a multiple sclerosis animal model by a novel nanodrop formulation of a natural antioxidant [Corrigendum]
}

Binyamin O, Larush L, Frid K, et al. Int J Nanomedicine. 2015;10:7165-7174.

On page 7165, the first affiliation and correspondence details were incorrectly written as "Department of Neurology,
The Agnes Ginges Center of Human Neurogenetics, Hadassah University Hospital". It should be "Department of Neurology, The Agnes Ginges Center of Human Neurogenetics, Hebrew University-Hadassah Medical Center”.
International Journal of Nanomedicine

\section{Publish your work in this journal}

The International Journal of Nanomedicine is an international, peerreviewed journal focusing on the application of nanotechnology in diagnostics, therapeutics, and drug delivery systems throughou the biomedical field. This journal is indexed on PubMed Central, MedLine, CAS, SciSearch ${ }^{\circledR}$, Current Contents ${ }^{\circledR} /$ Clinical Medicine,

\section{Dovepress}

Journal Citation Reports/Science Edition, EMBase, Scopus and the Elsevier Bibliographic databases. The manuscript management system is completely online and includes a very quick and fair peer-review system, which is all easy to use. Visit http://www.dovepress.com/ testimonials.php to read real quotes from published authors. 